\title{
CONTINUOUS PROFESSIONAL DEVELOPMENT OF JUNIOR HIGH SCHOOLS' ISLAMIC RELIGIOUS EDUCATION TEACHERS AT BANDAR LAMPUNG CITY, INDONESIA
}

\author{
Siti Robiyah ${ }^{*}$, Koderi2*, Syaiful Anwar ${ }^{3}$, Juhri Abdul Muin ${ }^{4}$, Umi Hijriyah ${ }^{5}$ \\ Postgraduate Program of Raden Intan State Islamic Universiry of Lampung, Indonesia \\ *sitirobiyah.s3mpilampung@gmail.com
}

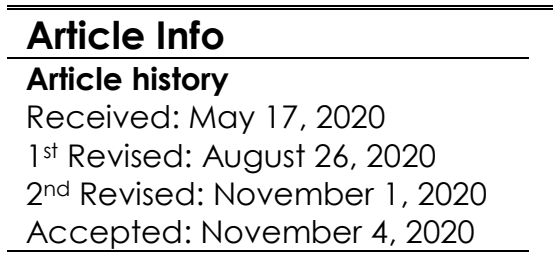

\section{Keywords:}

Innovative works;

Management;

Professional development;

Scientific publications;

Teachers.

\begin{abstract}
The purpose of this study was to determine the continuous professional development which covers self-development, scientific publications, and innovative works on Islamic religious education teachers in Bandar Lampung city, Indonesia. This study employs the qualitative-descriptive approach with the teachers, principals, the chairperson of Islamic religious education Subject Teachers' Conference (MGMP), and the head of State Office of Education Bandar Lampung as the sources of data. The data collected through interviews, observations, and documentation. The data analysis techniques used were data triangulation through data reduction, data presentation, and conclusion drawing. This study discovers that 1) to develop themselves, the teachers join MGMP activities, training, workshops, seminars, and others, 2) for scientific publications in the form of scientific papers, the teachers participate in the national level competitions and workbooks writing although, in a minimal amount, 3) for innovative work, the teachers prepare the learning standards, learning guidelines, semester exam questions, syllabus development, lesson plan development, teaching materials development, editing blueprints of Islamic religious education questions although without continuous innovation. It recommended to foster self-development, scientific publications, and work innovation, PAl teachers in junior high schools should take part in training, seminars, and workshops, both independently and held by the education offices by taking into account good management theories, namely activities designed based on needs analysis, coordination with all institutions. The implementation of activities should have precise and measured outputs. An evaluation is also needed to find out whether the selfdevelopment, scientific publications, and innovative works have achieved or not.
\end{abstract}

\section{INTRODUCTION}

Islamic religious education teachers are an integral part of the educational organization system in schools. They could deal with changing times that are so rapid and massive. For this reason, it is necessary to develop organizational performance collectively, including human resources. Teachers individually and together with their professional community must be encouraged to become part of the learning organization through their conscious and voluntary involvement and continuous involvement in various learning activities to develop their professionalism (Mulyasa, 2013). Islamic religious education teachers have the main task 
of educating, teaching, guiding, directing, training, assessing, and evaluating. Islamic religious education teachers' task is vital in preparing a future generation with strong faith, piety, and technological knowledge. The teachers must be innovative in education and learning if they want to be called professional teachers.

Teachers have a significant impact on their students. The instructional strategies applied by the teachers need to be carefully selected. The theory suggests that teachers serve as a guide to enhance students' learning (Koderi, 2017). This opinion explains that teachers have an essential role in the success of students' learning. Therefore, there needs to be an effective strategy to increase teachers' resources to have continuous professionalism in their work line. Teacher professional development in this research is a form of continuous learning for teachers to bring out the desired educational success changes. It is in line with the Regulation of the Minister of State for Administrative Reform and Bureaucracy Reform No. 16/2009 (Peraturan Menteri Negara Pendayagunaan Aparatur Negara dan Reformasi Birokrasi Nomor 16 Tahun 2009 Tentang Jabatan Fungsional Guru dan Angka Kreditnya, 2009) concerning Teacher Functional Position and Credit Scores, 2009 which states that the duties of the teachers are not only to teach, guide, and assess, but also must develop continuous professional development which includes self-development, scientific publications, and innovative works. Through continuous professional development, teachers expected to maintain, improve, expand their knowledge and skills, and build the personal qualities needed in their professional duties.

Professional Islamic education teachers are teachers who can implement their competencies according to academic qualifications. Teachers must show their performance optimally so that the learning success can be achieved and fulfilled according to the times' demands. As Allah, the almighty says "Do (as you will), for Allah will see your deeds, and (so, will) His messenger and the believers. Moreover, It will be returning to the knower of the unseen and the witnessed, and He will inform you of what you used to do" (Q.S. At- Taubah:105). Based on the verse of Islam professionals, especially in education, teachers must have quality education and good innovation to support their professional duties. The Prophet Muhammad said "If a case is not left to an expert, wait for its destruction" H.R. Bukhari (Tafsir, 1991). If the teachers' duties delegated to someone who is not a professional, it is difficult to achieve success in education, and even the entire educational organization will fail.

Based on preliminary research, it was knowing that there were 77 Islamic religious education teachers in junior high schools in Bandar Lampung. They consisted of 45 echelons III and 32 echelons IV. The percentage of teachers who were facing obstacles in promotion from echelon IV/a to IV/b for four years was one person (3.13\%), for five years were five people (15.62\%), for eight years were two people (6. 25\%), for nine years was three people (9.38\%), for ten years was one person (3.13\%), and 20 people (62.5) were not promoting. Based on the promotion data, it can be assuming that Islamic religious education teacher is slow in 
promotion due to lack of scientific publications and innovative works although they have participated in many education and training activities,

Wijaya's have carried out previous research on professional development. It can conclude that continuous professional development held by PPPPTK Matematika Yogyakarta does not have much impact on the change in alumni's behaviour (Wijaya, 2017: 1). Unlike the research conducted by Dudung, continuous professional development can improve educational services in schools to improve the quality of education, accelerate the process of making scientific papers, have skills in writing scientific papers based on the development of the teaching profession, and can improve the quality of scientific writing as the material for promotion (Dudung, 2014).

This phenomenon encouraged further research to focus on the continuous professional development of Islamic religious education junior high school teachers in Bandar Lampung. This study's sub-focus was 1) teachers' self-development, 2) development of scientific publications, 3) development of innovative works. This study aimed to find out in-depth about the continuous professional development of junior high school Islamic religious education teachers in Bandar Lampung, Indonesia, and to know 1) How is the self-development process? 2) How to develop the scientific publications?, and 3) how to develop the innovative works?

The results of this study are expected to be used by 1) the head of the state education office Bandar Lampung, the junior high school's supervisors, the principals, LPMP (education quality assurance institution), and IPTK as a reference in carrying out the training and professional development of islamic religious education teachers, 2) the school in improving and developing continuous professional development, especially islamic religious education teachers, and 3) improving the professional competence in continuous professional development and career of islamic religious education teachers independently.

\section{METHODS}

It is a descriptive-qualitative study (commonly called taxonomic research), which is the exploration and clarification of a phenomenon or social reality by describing several variables related to the problem and the unit studied (Asri et al., 2015; Mulyadi, 2011). The data sources were teachers, principals, the chairperson of Islamic religious education Subject Teachers' Conference (MGMP), and State Education Office Bandar Lampung's head. The data collecting techniques employed were interviews, observations, and documentation. The data analysis technique used was the triangulation technique through data reduction, data presentation, and conclusion drawing. The research design described as figure 1. 


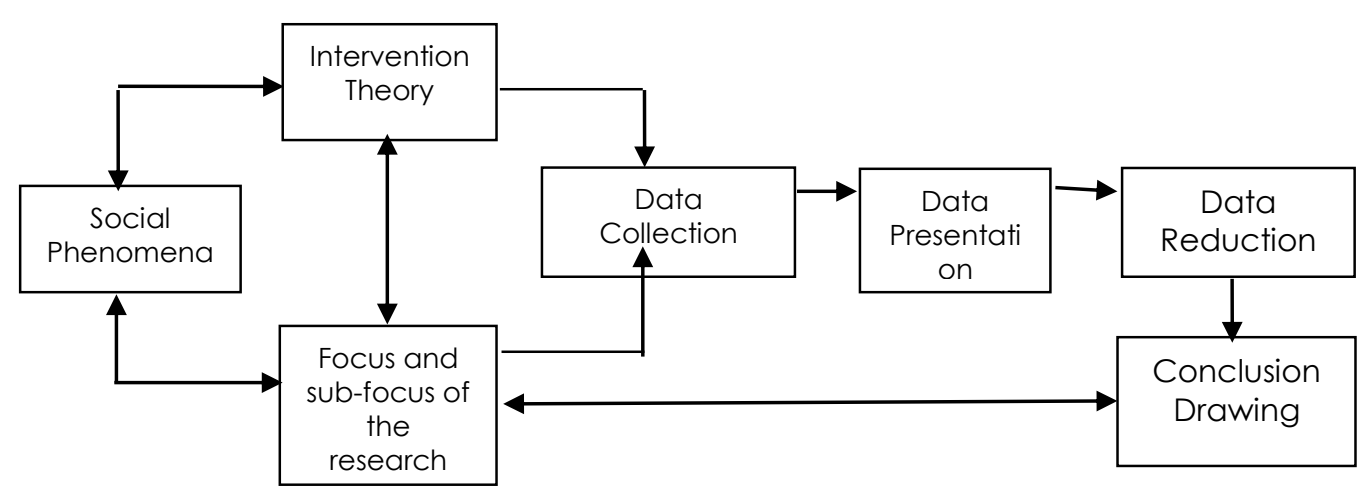

Figure1. Continuous Professional Development Research Design

\section{RESULTS AND DISCUSSION}

The data collection collected at several junior high schools in the city of Bandar Lampung. The private and public schools were selected based on the quality category. The schools that belonged to the excellence category were SMP N 25 Bandar Lampung and SMP Muhammadiyah 3 Bandar Lampung. The schools that belonged to the excellent category were SMP 37 Bandar Lampung and SMP Dharma pala Bandar Lampung. The schools that belonged to the moderate category were SMP N 32 Bandar Lampung and SMP Muhammadiyah 5 Bandar Lampung. The findings of the continuous professional development of junior high schools Islamic religious education teachers in Bandar Lampung presented.

\subsection{Continuous Professional Development of PAI Teachers}

The continuous professional development activities at the junior high schools in Bandar Lampung had structured and run according to the guidebook (Wijaya, 2017). Unfortunately, not all Islamic religious education teachers in the state and private junior high schools in Bandar Lampung can participate in these activities. Teachers who took part in the activities were only the civil servants and permanent teachers who were already certified. The activities carried out by the junior high schools in Bandar Lampung covered three components, namely selfdevelopment, scientific publications, and innovative work.

\subsection{Self-development}

The researchers obtained the data on the professional development of Islamic religious education teachers'. According to several teachers, they had participated in seminar activities in the national, regional, and even international. Furthermore, interviews with the head of the Education Office discovered that the government had provided training for teachers. The training held in groups, including training for Islamic religious education teachers, PKG (Teacher Work Assessment) for PAI teachers, and Islamic religious education Subject Teachers' Conference (MGMP). Strengthening teachers' work at the PKG activities 
level is ordinary teachers, namely subject teachers with various educational backgrounds and very diverse educational fields, ranging from D1 to S1 levels.

The results of an interview with the chairperson of the MGMP revealed that in developing themselves, the Islamic religious education teachers took some steps, namely fostering teacher excitement to improve the ability and skills in preparing, implementing, and evaluating teaching and learning activities programs, equalizing the ability and skills of teachers in implementing the teaching and learning activities so that they can support efforts to improve and equalize the quality of education, discussing issues faced by teachers in carrying out daily tasks and looking for the solutions that are appropriate to the characteristics of the subjects, methods, media, time management, school conditions, and the environment.

The interview results on Islamic religious education teachers' self-development in Bandar Lampung revealed that Islamic religious education teachers have tried to make and implement lesson plans. The lesson plans constructed from the opening activities to implementing the core learning activities, methods and evaluation, and the closing activities. Through some observations, the researchers joined the teaching and learning activities. They witnessed that the Islamic religious education teachers opened the lesson by posing several questions to students about the past material. The teachers asked students to hold discussions in the predetermined groups. In the discussion activities, the teachers acted as moderators and observers. After the discussions had ended, the teachers explained the answers to students' questions in detail. When closing the lesson, the teachers, together with the students, concluded the discussions, and the teacher gave individual assignments to the students. It appeared that the most effective learning methods were the discussion and assignment methods.

The results obtained were confirmed by the Regulation of the State Minister for Empowerment of State Apparatuses and Bureaucratic Reformation No. 16/2009. Schools are required to allow every teacher to participate in the PKB program, with a minimum number of hours per year as specified. District/city Education Offices and schools have the right to increase the time allocation if deemed necessary. According to their needs, for teachers who do not show improvement after participating in the development programs, it is possible to be given sanctions following statutory provisions. These sanctions do not apply to teachers if schools cannot meet teachers' needs to implement the programs. The scope of material for continuous professional development activities must focus on student learning and rich in educational material (Wijaya, 2017).

Bayar (n.d.) states that the programs of continuous professional development have applied in various countries, one of which is in Turkey called continuing professional development (CPD). Bayar also states that practical activities in continuing professional development must have several components, namely: 1) compatibility with the needs of existing teachers, 2) compatibility with the needs of existing schools, 3) teacher involvement in 
designing/planning of professional development activities, 4 ) opportunities for active participation, 5) long-term involvement, and 6) high-quality instructors. Without one of these components, the programs will not run effectively because these components are interrelated. A program can be useful if it meets the six components (Bayar, n.d.).

It is in line with Khoirina and Gunansyah's (2018) research that there are still many teachers who do not take part or are less active in participating in continuous professional development activities, both in training and seminars. The teachers' opportunity for active participation was not responding to well so that the activities look passive without reciprocity from the teachers or audiences. Therefore, the teacher's continuous professional development activities regarding self-development must always be increased and full of supervision.

\subsection{Development of Teacher Scientific Publications}

According to the information from several teachers, junior high school Islamic religious education teachers in Bandar Lampung have produced scientific works such as classroom action research, articles published in newspapers, magazines, and some have even published books, even though they were limited to textbooks (An interview on September 3, 2019). According to Mila Marlina, functional training and education activities teach the teachers to write classroom action research. The classroom action research is in the form of educational journal articles, and so on. The class action research results will be published in several printed media such as magazines in the next stage. One magazine that usually publishes the results of classroom action research studies is the education magazine. (An interview on September 4, 2019). However, based on the comprehensively analyzed data, the Islamic religious education teachers' publications in Bandar Lampung can be classified as low in quantity.

According to The Regulation of The Ministry of Administrative and Bureaucratic Reform number 16 of 2009, several activities can be carried out by the Islamic religious education teachers in increasing the quality of scientific papers, namely;

1) They carried out socialization of The Regulation of The Ministry of Administrative and Bureaucratic Reform number 16 of 2009 to Islamic religious education teachers and supervisors. The purpose of this socialization activity is to provide teachers and supervisors with a correct understanding of what activities teachers must carry out in fulfilling their obligations to improve their competence and develop their careers continuously. This socialization also opens up teachers' insights and understanding of the obligations that must follow and how to achieve maximum results from these self-development activities. The main objective to be achieved is to increase the competence of Islamic religious education teachers and supervisors to improve the quality of education that they manage. This socialization activity can carry out through the Islamic religious education

Subject Teachers' Conference (MGMP) and the Islamic religious education Supervisory Working Group. 
2) They were conducting continuous professional development workshops to understand what activities can be followed by teachers and supervisors to improve and develop professional skills. Also, Islamic religious education teachers and supervisors can optimize their potential to achieve maximum work performance through promotion according to procedures. This kind of workshop had been carried out by the Regional Office of the Ministry of Religious Affairs of Aceh using the budget funded by DIPA. This activity attended by representatives of Islamic religious education teachers from many districts/cities and PAI supervisors' representatives also attended it.

3) They were conducting a workshop on scientific papers/innovative works. For this reason, the Islamic religious education Division of the Lampung Province Ministry of Religious Affairs conducted such workshops. This activity planned to carry out in each district/city through coordination and collaboration with the Ministry of Religious Affairs and the Ministry of Education. The workshop activities' funding was obtained from the workshop participants themselves so that the limited budget available at DIPA did not hinder the activities. The workshops' purpose on scientific/innovative works is to improve PAl teachers' and supervisors' competence in writing scientific papers and producing other innovative works. The teacher needs scientific works competency, especially in carrying out research activities in the classrooms known as Classroom Action Research (CAR). CAR activities are carried out by teachers to solve classroom problems during learning activities, such as low student achievement, motivation, interest, and passive student activities. These various problems affect the students' achievements, so efforts to improve let teachers carry out CAR activities shops also motivate teachers to produce art relevant to their respective talents and interests. They can be used to fulfil credit points to promote.

4) Publishing Scientific Journals. The Islamic religious education Division has made other efforts of the Lampung Province Ministry of Religious Affairs to motivate, develop, and enhance PAI teachers and supervisors' competence to publish ISSN scientific journals in the printed form called Cendekia Scientific Journal of Islamic Education. This scientific journal aims to help Islamic religious education teachers and supervisors accommodate their scientific papers to be widely documented and circulated to be utilized by many people. Also, the Scientific Journal's presence expected to motivate teachers to write and share information with others.

5) Web publishing. The blog of the Islamic religious education Division of the Lampung Province Ministry of Religious Affairs provides Information about PAl programs and exposures. It needs to done so that teachers, supervisors, and stakeholders can participate in these programs' success. This blog also acts as an online scientific journal. PAl teachers and supervisors can see and read the published scientific works. It hoped that the spread of scientific works could enjoy widely. 
6) Facilitating the publication of Islamic religious education teacher's and supervisors' books. The long-term activity that will be programmed and implemented by the Islamic religious education Division of the Lampung Province Ministry of Religious Affairs is to assist and facilitate the issuance and management of ISBN books by Islamic religious education teachers and supervisors (Junus, 2009)

Whether independent, collaborative, or institutional, scientific publications are relatively low based on the data. It is in line with Sholeh's opinion that writing scientific papers is a familiar problem teacher's face. Time constraints also cause limited ability because certified teachers must teach 24 hours per week. Writing research takes time, and the process of publishing scientific papers also requires a long process, starting from the received, reviewed, and publication process (Sholeh et al., 2015). In contrast to Supriyono's opinion, if the teachers contained by time limitation, they should optimize the time to focus on CAR (Classroom Action Research) by setting aside a specific time to work on CAR. Teachers often stuck in work routines from time to time. Routine tasks become a daily activity, and sometimes there are additional tasks that are very time-consuming. If the teacher is facing the standard conditions, it should be wise to set aside time for CAR. CAR can also use as a routine work of teachers to be integrated with other routine tasks by implementing CAR as a routine activity of the teachers. If it has become a routine activity, the teacher accustomed to doing it (Supriyanto, 2017).

\subsection{Innovative Works}

Innovative works are development, modification, or discovery as a form of teachers' contribution to improving the quality of the learning process in schools and developing education, science, technology, and art. This innovative work includes 1) the discovery of appropriate technology in the complex and straightforward categories, 2) the discovery or development of complex and straightforward artwork categories, 3) manufacture or modify the learning tools, teaching aids in the complex or simple categories, and 4) preparation of standards, guidelines, questions, and the like at the national or provincial level. It is in line with Waryono's opinion that innovative works are works in the forms of development, modification, or discoveries as a form of teacher's contribution to improving the quality of the learning process in schools and the development of education, science, technology, and art. The innovative works are not the same as scientific publications. The innovative works produce objects, whereas scientific publications produce scientific papers. Generally, the rejected innovative works need to be improved while the rejected scientific publications need to remake. The attachments of the innovative works are in the form of photos, videos, and acknowledgement, while the attachments of scientific publications are in the form of supporting evidence, lesson plans, questions, and test results (Waryono, 2017).

Furthermore, the results of interviews with Zainal Hakim Kasi Pakis of the Regional Office of the Lampung Province Ministry of Religious Affairs and the head of PAl Subject Teachers'

IJEMI Vol.2, No.1, January 2021, pp. 44 54 
Conference (MGMP), Mulyano, and one of the principals in Bandar Lampung, Euis Tati Darnati, said that only 2 Islamic religious education teachers carried innovative works out of 120 junior high schools PAI teachers in Bandar Lampung. It caused by no coaching available, and the Islamic religious education teachers and supervisors in Bandar Lampung experienced problems in developing innovative work competencies. Kinkel states that teachers have not been able to have innovative works because they cannot create new knowledge (Kinkel et al., 2017). Therefore. Workshops are necessary to develop innovative works, motivate the teachers to produce innovative works relevant to their respective talents and interests, and fulfil credit scores to be promoted.

In contrast to previous research conducted by Wuryandini (2014), a small proportion of teachers had implemented continuous professional development, and most teachers had implemented agreements. However, they did not fulfil all the sub-elements of continuous professional development. Their credit score did not meet the minimum credit score required. Wijaya and Sumarno (2017) found that education and training for the continuous professional development of mathematics teachers had a low impact on alumni's behaviour in carrying out continuous professional development activities. According to Maiza and Nurhafizah (2019), teachers can improve their competency test scores (UKG) through a continuous professional development program as a medium for self-development to become better.

Therefore, this research on the professional development of Islamic religious education teachers in Bandar Lampung is different from previous studies in terms of the depth study. This research investigated overall continuous professional development to find positive and negative aspects as well as their impacts.

\section{CONCLUSION}

The results of this research are 1) the teachers need to develop themselves by participating in Islamic religious education Subject Teachers' Conference (MGMP)activities, training, seminars, workshops, and other activities, 2) the teachers had published scientific publication in the form of scientific papers, participated in the national level competitions and advanced student workbooks although very few, and 3) for the innovative works, the teachers prepared the teaching and learning standards, prepared the teaching and learning guidelines, prepared semester exam questions, developed syllabus, developed lesson plans, developed teaching materials, developed specification of PAl questions although not yet continuously innovated.

\section{ACKNOWLEDGMENTS}

The researchers express their gratitude to all Islamic religious education teachers, all principals of junior high schools, Islamic religious education Subject Teachers' Conference (MGMP), head of education offices Lampung, post-graduate lecturers of UIN Raden Intan 
Lampung. The latter has guided and provided research data and information on the continuous professional development of junior high school Islamic religious education teachers in Bandar Lampung.

\section{REFERENCES}

Asri, Tolla, I., Jufri, M., \& Dirawan, G. D. (2015). The effects of cooperative learning "SAVI" (Somatis, Auditori, Visual and Intelektual) approach to consciousness metacognitive and learning ecosystem at Senior High School 1 Tanete Rilau. Man in India, 95(4), 1061-1069. Bayar, A. (n.d.). The Components Of Effective Professional Development Activities In Terms Of Teacher Perspective. Journal Of Educational Sciences, Vol. 6(2), 319-327.

Dudung, A. (2014). Pelatihan Pengembangan Keprofesian Berkelanjutan (PKB) Bagi Guru Guru Se Jakarta Timur. Sarwahita, 11 (1), 13. https://doi.org/10.21009/sarwahita.111.03 Junus, N. (2009). Tentang Jabatan Fungsional Guru Dan Angka Kredit ( Studi Kasus pada Kenaikan Pangkat dan Dampaknya Bagi Guru SDN di Kecamatan Kandis Kabupaten Siak ). Jurnal Manajemen Pendidikan Penelitian Kualitatif, 2(3), 225-230.

Khoirina, L., \& Gunansyah, G. (2018). Implementasi Program Pengembangan Keprofesian Berkelanjutan Di Sekolah Dasar Gugus 1 Kecamatan Rejoso Kabupaten Nganjuk. Jurnal Penelitian Pendidikan Guru Sekolah Dasar, 6(8), 1427-1437.

Kinkel, S., Schemmann, B., \& Lichtner, R. (2017). Critical Competencies for the Innovativeness of Value Creation Champions: Identifying Challenges and Work-integrated Solutions. Procedia Manufacturing, 9(0), 323-330. https://doi.org/10.1016/j.promfg.2017.04.021

Koderi. (2017). Pengembangan Modul Elektronik Berbasis SAVI Untuk Pembelajaran Bahasa Arab. Teknologi Pendidikan, 19(3), 206-223. https://doi.org/https://doi.org/10.21009/JTP1903.4

Maiza, Z., \& Nurhafizah, N. (2019). Pengembangan Keprofesian Berkelanjutan dalam Meningkatkan Profesionalisme Guru Pendidikan Anak Usia Dini. Jurnal Obsesi : Jurnal Pendidikan Anak Usia Dini, 3(2), 356. https://doi.org/10.31004/obsesi.v3i2.196

Mulyadi, M. (2011). Penelitian Kuantitatif Dan Kualitatif Serta Pemikiran Dasar Menggabungkannya. 15(1), 127-138.

Mulyasa. (2013). Uji Kompetensi dan Kinerja Guru (1st ed.). PT Remaja Rosdakarya.

Peraturan Menteri Negara Pendayagunaan Aparatur Negara dan Reformasi Birokrasi Nomor 16 Tahun 2009 tentang Jabatan Fungsional Guru dan Angka Kreditnya, (2009).

RI, D. A. (2009). Al-Quran dan Terjemahnya. PT. Syaamil Cipta Media.

Sholeh, M., Susetyo, J., \& Hapsari, P. (2015). IbM Kelompok Guru Sebagai... (Sholeh dkk.) IbM Kelompok Guru Sebagai Upaya Meningkatkan Kompetensi Profesional Melalui Pendampingan Penulisan Karya Tulis IImiah Dan Pemanfaatan Media Pembelajaran Berbasis Teknologi Informasi. Proseding Seminar Nasional Sain Dan Teknologi Fakultas 
Teknik Universitas Wahid Hasyim Semarang, 1 (1), 98-103.

Supriyanto, A. (2017). Peningkatan Kemampuan Guru Dalam Penulisan Karya Ilmiah Melalui Pelatihan Penelitian Tindakan Kelas. Abdimas Pedagogi, 1 (1), 1-7.

Tafsir, A. (1991). Ilmu Pendidikan Dalam Perspektif Islam. PT. Remaja Rosdakarya.

Waryono. (2017). Menjadi Guru Profesional melalui Penyusunan Karya Inovasi. LPMP D.I. Yogyakart.

Wijaya, A. (2017). Evaluasi Dampak Pendidikan Dan Pelatihan Pengembangan Keprofesian Berkelanjutan Guru Matematika Di Pppptk Matematika Yogyakarta. IEEE International Conference on Acoustics, Speech, and Signal Processing (ICASSP) 2017, 41 (2), 84-93.

Wijaya, A., \& Sumarno, S. (2017). Impact Evaluation of Mathematics Teachers' Continuing Professional Development Education and Training at Yogyakarta Mathematics and Social Sciences Teacher Training Center. Jurnal Penelitian Dan Evaluasi Pendidikan, 21 (2), 127-141. https://journal.uny.ac.id/index.php/jpep/article/view/10113/10219

Wuryandini, E. (2014). Analisis Permasalahan Dan Kebutuhan Pengembangan Keprofesian Berkelanjutan Guru Smk Bidang Keahlian Bisnis Dan Manajemen Pascasertifikasi Di Kota Semarang. Jurnal Manajemen Pendidikan Universitas Muhammadiyah Surakarta, 09(2), 108-1 19. https://doi.org/10.23917/jmp.v9i2.1692 